\begin{tabular}{|c|c|}
\hline & PORT SAID ENGINEERING RESEARCH JOURNAL \\
Faculty Of Engineering - Port Said University \\
Volume 21 No. 1 March 2017 pp. 49:58
\end{tabular}

\title{
A Study to Distinguish Between Wastewater Treatment Plants in Rural Egypt
}

\author{
Mamdouh Y. Saleh ${ }^{1}$, Medhat H. El-Zahar ${ }^{2}$, Nehal M. Ashour $^{3}$
}

\begin{abstract}
Several wastewater treatment plants technologies have been set up in the Egyptian villages; however, the most efficient and economical technology hasn't been determined. This research aims to distinguish between the wastewater treatments plants which are used in rural Egypt to find out the best between them. The data about Centralized and Decentralized wastewater treatment plants which are used in rural Egypt using group of factors has been collected to distinguish between the characterizations of these plants by doing a questionnaire to evaluate the weight of these factors. The questionnaire has been given to experts to evaluate the factors for getting relative weights of them. Expert evaluated the factors according to his importance by choosing a mark from the lowest value one to the highest value ten. After receiving the results of the questionnaire from the experts, the data were processed to find out the best group of results of these plants. The largest percentage of Relative Weights of factors is Efficiency, followed by Costs, Average load removed, Specific surface area, Average flow and Average population. The best three centralized wastewater treatment plants were from the aerobic treatment.
\end{abstract}

\section{KEYWORDS: Wastewater Treatment, Centralized WWTP, Decentralized WWTP, Rural areas}

\section{Introduction}

Most of Egypt's populations are still without improved sanitation; almost three quarters of them live in rural areas which is the people's sewage of liquid wastes and its unhealthy treatment which caused the underground water level to rise. It was also the cause of the seepage of water to streams and canals and eventually comes back to the drinking water and agricultural crops. This, in turn, resulted in a large number of the population catching the liver and kidney disease. So the research aims to distinguish between the wastewater treatment plants which are used in rural Egypt to find out the best between them. After finding the best systems, we can recommend to use these systems for serving other rural areas that have no treatments.

\subsection{Objectives of Current Research}

The objectives of this study were to:

1) Finding a new method for clear evaluation of the most effective factors on the wastewater treatment plants existing in rural Egypt.

2) Deciding the best of these plants according to that evaluation of the influential factors and in same time concentrating on reaching the lowest cost.

3) Using LCCA method to find out the lowest cost among the chosen plants, concerning the cost of (construction- maintaining and energy)

${ }^{1}$ Civil Engineering Department, Faculty of Engineering, Port Said University, Port Said, Egypt.

${ }^{2}$ Civil Engineering Department, Faculty of Engineering, Port Said University, Port Said, Egypt.

${ }^{3}$ Civil Engineering Department, Faculty of Engineering, Port Said University, Port Said, Egypt, E-mail : nehalashoor22@yahoo.com

\section{Literature Review}

\subsection{Aerobic Treatment}

The basic aerobic treatment process involves providing a suitable oxygen rich environment for organisms that can reduce the organic portion of the waste into carbon dioxide and water in the presence of oxygen.

\subsubsection{Activated Sludge System}

Activated sludge system is currently the most widely used biological wastewater treatment process especially in Egypt.

It described as activated sludge because of presence of active microorganisms is returned to the aeration tank to continue biodegradation of the influent organic material.

An activated sludge process refers to a multichamber reactor unit that makes use of highly concentrated microorganisms to degrade organics and remove nutrients from wastewater to produce a highquality effluent. To maintain aerobic conditions and to keep the activated sludge suspended, a continuous and well-timed supply of oxygen is required.

Activated sludge consists of flocs of bacteria, which are suspended and mixed with wastewater in an aerated tank. The bacteria use the organic pollutants to grow and transform it to energy, water, $\mathrm{CO} 2$ and new cell material. Activated sludge systems are suspendedgrowth type and are used in conventional high-tech wastewater treatment plants to treat almost every wastewater influent as long as it is biodegradable. A physical pre-treatment unit, a post-settling unit (a clarifier) from which active sludge is re-circulated to the aerated tank, and excess sludge treatment, are 
compulsory for appropriate treatment. The process is highly mechanized and thus mainly adapted for centralized systems where energy, mechanical spare parts and skilled labor are available. Provided the reactor is well operated, a very good removal of organics and suspended solids can be achieved, though pathogen removal is low, [1].

\subsubsection{Extended Aeration}

The extended-aeration process is a modification of the conventional activated-sludge process. It is generally commonly used to treat the wastewater generated from small rural communities. The system consists of a single or multiple basins designed for completely mixed flow, followed by a settling basin to separate the mixed liquor solids the treatment wastewater. In extended aeration activated-sludge detention time is increased by a factor of four or five compared to conventional activated-sludge. The main advantages of the extended-aeration process is that the amount of excess biological solids (sludge) produced is eliminated or minimized, [2].

\subsubsection{Sequencing Batch Reactors}

The sequencing batch reactor (SBR) is considered a fill-and-draw activated sludge system. The processes of equalization, aeration, and clarification are all achieved in the same tank, unlike a conventional activated sludge system, in which the same processes are accomplished in separate tanks. Wastewater is added to the tank, treated to remove undesirable components, and then discharged. SBR systems consist of five common steps carried out in sequence: (1) fill, (2) react (aeration), (3) settle (sedimentation/ clarification), (4) draw (the effluent is decanted), and (5) idle. Sludge wasting usually occurs during the settling phase, [3].

\subsubsection{Oxidation Ditches}

The oxidation ditch is an extremely effective variation of the activated sludge process, consisting of a ring or oval shaped channel equipped with mechanical aeration devices, such as brush rotors or disc aerators. Oxidation ditches typically operate in an extended aeration mode with long solids retention times (SRTs). Solids are maintained in suspension as the mixed liquor circulates around the ditch. Preliminary treatment involves bar screens and grit removal. Secondary sedimentation tanks are used for most applications. Tertiary filters may be required after clarification and disinfection. Re-aeration may be necessary prior to final discharge, [3].

\subsubsection{Aerated Lagoons}

Aerated Lagoon: The aerated lagoon is a basin in which wastewater is treated either on a flow - through basis or with solid recycle. Oxygen is usually supplied by a means of surface aerators or diffused-air aeration units. Aerated lagoon process is essentially the same as the conventional-aeration activated sludge process, except that an earthen basin is used for the reactor and the oxygen required by the process is supplied by surface or diffused aerators. Seasonal and continuous nitrification may be achieved in aerated lagoon system. The degree of nitrification depends on the design and operation condition within the system and on the wastewater temperature. Generally, with high wastewater temperature and lower loadings, higher degree of nitrification can be achieved, [2].

\subsubsection{Trickling Filters}

The liquid effluent from the primary settling tank is passed to the secondary part of the system where aerobic decomposition completes the stabilization. For this purpose, a trickling filter is used.

A trickling filter is a fixed bed, biological filter that operates under (mostly) aerobic conditions. Pre-settled wastewater is 'trickled' or sprayed over the filter. As the water migrates through the pores of the filter, organics are degraded by the biomass covering the filter material, [4].

\subsubsection{Dual Flow Aerated Bio-Filters}

To further increase performance and simplify operation of the aerated filter, a new up flow biofilter system has been recently developed. For TSS, BOD and COD, the average removal ratio was $90 \%, 89 \%$ and $90 \%$ respectively for the total system. The up-flow filter gave an average removal efficiency of $28 \%$ TSS at 35 average influent concentration $83 \mathrm{mg} / \mathrm{l}$ and average effluent concentration $59 \mathrm{mg} / \mathrm{l}$. This value was considerably high, in spite of the absence of clarifier after the upflow filter and this could be attributed to that most of the suspended solid accumulated with the biomass was entrapped into the void spaces of the packed media of the up flow filter, [2].

\subsubsection{Rotating Biological Contactor System}

Rotating biological contactor systems normally make use of bar screens and/or comminutors, grit chambers, primary settling tanks, secondary tanks, and digesters, which are operated in the same manner as those of trickling filter systems. The rotating biological contactor (RBC) is a simple, effective method of providing secondary wastewater treatment. The system consists of biomass media, usually plastic, that is partially immersed in the wastewater. As it slowly rotates, it lifts a film of wastewater into the air. The wastewater trickles down across the media and absorbs oxygen from the air. A living biomass of bacteria, protozoa, and other simple organisms attaches and grows on the biomass media. The organisms then remove both dissolved oxygen and organic material from the trickling film of wastewater. Any excess biomass is sloughed-off as the media is rotated through the wastewater. This prevents clogging of the media surface and maintains a constant microorganism population. The sloughed-off material is removed from the clear water by conventional clarification. The RBC rotates at a speed of one to two $\mathrm{rpm}$ and provides a high degree of organic removal, [4]. 


\subsection{Anaerobic Treatment}

Anaerobic digestion is a fermentation process in which organic material is degraded and biogas (composed of mainly methane and carbon dioxide) is produced. Anaerobic digestion processes occur in many places where organic material is available and redox potential is low (zero oxygen). This is typically occurring in stomachs of ruminants, in marshes, sediments of lakes and ditches, municipal landfills, or even sometimes in municipal sewers. Anaerobic treatment is also effective in removing biodegradable organic compounds and producing mineral compounds such as NH4+, PO4-, and CO2- in the solution. The amount of excess sludge produced is very small and well stabilized and may have a market value, if granular anaerobic sludge is produced in the bioreactor. Moreover, useful energy in the form of biogas is produced instead of requiring high-grade energy Atypical Functional units of a sewage treatment plant, comparing activated sludge and UASB technology, [5].

\subsubsection{Up Flow Anaerobic Sludge Blanket} (UASB) Reactor

The UASB reactor consists of a circular or rectangular tank in which waste (water or sludge) flows in an upward direction through an activated anaerobic sludge bed which occupies about half the volume of the reactor and consists of highly settleable granules or flocs. During the passage through than aerobic sludge the treatment process takes place by solids entrapment and organic matter conversion into biogas and sludge. The produced biogas bubbles automatically rise to the top of the reactor, carrying water and solid particles, i.e. biological sludge and residual solids. The biogas bubbles are (via baffles) directed to a gas-liquid surface at the upper part of the reactor, leading to an efficient GLSS. The solid particles drop back to the top of the sludge blanket, while the released gases are captured in an inverted cone or related structure, located at the top of the reactor. Water passes through the apertures between the baffles carrying some solid particles which settle in the settling area because of the drop in upward velocity owing to the increase in the cross sectional area. After settling, the solids slide back to the sludge blanket, while water leaves the settlers over overflow weirs, [5].

\subsubsection{Anaerobic Baffled Reactor (ABR)}

An anaerobic baffled reactor (ABR) is an improved Septic Tank with a series of baffles under which the grey-, black- or the industrial wastewater is forced to flow under and offer the baffles from the inlet to the outlet. The increased contact time with the active biomass (sludge) results in improved treatment. ABRs are robust and can treat a wide range of wastewater, but both remaining sludge and effluents still need further treatment in order to be reused or discharged properly.

An ABR consists of a tank and alternating hanging and standing baffles that compartmentalize the reactors and force liquid to flow up and down from one compartment to the next, enabling an enhanced contact between the fresh wastewater entering the reactor and the residual sludge, containing the microorganisms responsible for anaerobic digestion of the organic pollutants. The compartmentalized design separates the solids retention time from the hydraulic retention time, making it possible to anaerobically treat wastewater at short retention times of only some hours [9]. Solids high treatment rates are high, while the overall sludge production is characteristically low, [7]. They are simple to build and simple to operate, as well as very robust to hydraulic and organic shock loading, [8]. Yet, both sludge and effluent still need further treatment.

\subsection{Natural Treatment}

Waste Stabilization Ponds (WSP) and Constructed Wetlands $(\mathrm{CW})$ have proven to be effective alternatives for treating wastewater, and the construction of low energy-consuming ecosystems that use natural processes, in contrast to complex high-maintenance treatment systems, will hopefully lead to more ecologically-sustainable wastewater treatment in the future, [6].

\subsubsection{Waste Stabilization Ponds:}

Waste Stabilization Ponds (WSPs) are large, shallow basins in which raw sewage is treated entirely by natural processes involving both algae and bacteria. They are used for sewage treatment in temperate and tropical climates, and represent one of the most costeffective, reliable and easily-operated methods for treating domestic and industrial wastewater. Waste stabilization ponds are very effective in the removal of faecal coliform bacteria. Sunlight energy is the only requirement for its operation. Further, it requires minimum supervision for daily operation, by simply cleaning the outlets and inlet works, [6].

\subsubsection{Constructed Wetlands}

Constructed wetlands (CWs) are planned systems designed and constructed to employ wetland vegetation to assist in treating wastewater in a more controlled environment than occurs in natural wetlands. Hammer (1990) defines constructed wetlands as a designed, manmade complex of saturated substrate, emergent and submerged vegetation, animal life, and water that simulate wetlands for human uses and benefits. Constructed wetlands are an "eco-friendly" alternative for secondary and tertiary municipal and industrial wastewater treatment. The pollutants removed by CW's include organic materials, suspended solids, nutrients, pathogens, heavy metals and other toxic or hazardous pollutants. In municipal applications, they can follow traditional sewage treatment processes. Different types of constructed wetlands can effectively treat primary, secondary or tertiary treated sewage.

\subsection{Centralized and Decentralized Wastewater Treatment Plants}

In most countries, centralized wastewater treatment plants are the typical facilities found in urban agglomerations. Households are connected to a sewage system, which, via underground carrier networks, transfers sewage away from the populated agglomeration to a single treatment facility that is 
usually far away from the point of wastewater generation. As such, small household pipes are connected to larger pipes and trunk mains, which are finally linked to the treatment plants. Such collection systems are expensive regarding their construction (digging and installation) and account for $70-90 \%$ of the capital costs.

However, where population density is low, decentralized systems are an alternative to the extensive centralized ones. This counts especially for rural areas, where population is scattered over a wide area.

Decentralized wastewater management in this regard is understood as the collection, treatment and re-use or disposal of wastewater at or near its point of generation.

These systems are smaller than the centralized ones and are usually localized, whereas in centralized systems, gravity sewers are in use; decentralized systems consist of small-diameter pressurized pipes, small-diameter gravity or vacuum sewers. In most cases decentralized systems are owned by the developer or nonpublic entities, [10].

\section{Evaluation Parameters}

\subsection{Data Collection}

Data has been collected about Centralized and Decentralized wastewater treatment plants which are used in rural Egypt for a group of factors.

Centralized wastewater treatment plants which data has been collected about them are ( Conventional activated sludge (CO) - Extended aeration (EX) Oxidation ditches (OX) - Waste stabilization ponds (WSP) - Trickling filters (TF) - Rotating Biological Contactors (RBC) - Aerated lagoon (AL) - Sequencing (UASB) - Wetlands (WL)).

Decentralized wastewater treatment plants which we collected data about them are (Activated sludge (AS) Waste stabilization ponds (WSP) - Anaerobic Filters (ABR) - Biological Aerated Filter (DABF) - Wetlands (WL)).

These factors are :

- Cost of operation and consumables/m3, Construction cost 1000/m3, Cost of operation and consumables/Kg BOD removed, Specific surface area $(\mathrm{m} 2 / \mathrm{m} 3)$, Average population (Inhabitants), Average flow m3/day, Average load removed (kg/day), Efficiency $\%$ BOD, Efficiency \%TSS, Power cost/Kg BOD removed, Power cost $/ \mathrm{m} 3$.

These data for Centralized and Decentralized WWTPs showed in the following tables:
Table 1: Technical and economic data characterizing selection matrix for Centralized WWTP

\begin{tabular}{|c|c|c|c|c|c|c|}
\hline \multirow{3}{*}{$\begin{array}{l}\text { Centralized } \\
\text { WWTP } \\
\text { Indicators }\end{array}$} & \multicolumn{6}{|c|}{ Aerobic } \\
\hline & \multicolumn{6}{|c|}{ Type of technologies } \\
\hline & $\mathrm{CO}$ & SA & EX & $\mathrm{TF}$ & OX & SBR \\
\hline $\begin{array}{c}\text { Average } \\
\text { population }\end{array}$ & 30000 & 15000 & 15000 & 30000 & 30000 & 50000 \\
\hline $\begin{array}{c}\text { Average } \\
\text { flow } \\
\text { m3/day }\end{array}$ & 6000 & 3000 & 3000 & 6000 & 6000 & 10000 \\
\hline $\begin{array}{l}\text { Average } \\
\text { load } \\
\text { removed } \\
\text { (kg/day) }\end{array}$ & 1476 & 771 & 788 & 2000 & 840 & 2767 \\
\hline $\begin{array}{c}\text { Efficiency } \\
\% \text { BOD }\end{array}$ & 84 & 89 & 87 & 76 & 85 & 90 \\
\hline $\begin{array}{c}\text { Efficiency } \\
\% \text { COD }\end{array}$ & 85 & 87 & 89 & 69 & 81 & 90 \\
\hline $\begin{array}{c}\text { Efficiency } \\
\% \text { TSS }\end{array}$ & 84 & 89 & 82 & 68 & 82 & 90 \\
\hline $\begin{array}{c}\text { Power } \\
\text { cost } / \mathrm{Kg} \\
\mathrm{BOD} \\
\text { removed }\end{array}$ & 0.2 & 0.2 & 0.3 & 0.1 & 0.2 & 0.4 \\
\hline $\begin{array}{l}\text { Power } \\
\text { cost } / \mathrm{m} 3\end{array}$ & 0.06 & 0.06 & 0.09 & 0.4 & 0.05 & 0.1 \\
\hline $\begin{array}{l}\text { Cost of } \\
\text { operation } \\
\text { and } \\
\text { consumabl } \\
\text { es/m3 }\end{array}$ & 0.3 & 0.6 & 0.6 & 0.2 & 0.1 & 0.4 \\
\hline $\begin{array}{c}\text { Constructi } \\
\text { on cost } \\
1000 / \mathrm{m} 3\end{array}$ & 2 & 1.5 & 7 & 6 & 3 & 11 \\
\hline $\begin{array}{l}\text { Cost of } \\
\text { operation } \\
\text { and } \\
\text { consumabl } \\
\text { es/ Kg } \\
\text { BOD } \\
\text { removed } \\
\end{array}$ & 1.6 & 1.4 & 1.4 & 0.5 & 0.2 & 0.7 \\
\hline $\begin{array}{l}\text { Specific } \\
\text { surface } \\
\text { area } \\
(\mathrm{m} 2 / \mathrm{m} 3)\end{array}$ & 2 & 2 & 3 & 3 & 2 & 1 \\
\hline
\end{tabular}

Table 2: Technical and economic data characterizing selection matrix for Centralized WWTP

[(AL - RBC- UASB- WL- WSP) plants]

\begin{tabular}{|c|c|c|c|c|c|}
\hline \multirow{2}{*}{$\begin{array}{c}\text { Centralized } \\
\text { WWTP }\end{array}$} & \multicolumn{2}{|c|}{ Aerobic } & \multicolumn{2}{|c|}{ Anaerobic } & \multicolumn{2}{|c|}{$\begin{array}{c}\text { Natural } \\
\text { treatment }\end{array}$} \\
\cline { 2 - 6 } & \multicolumn{5}{|c|}{ Type of technologies } \\
\hline Indicators & AL & RBC & UASB & WL & WSP \\
\hline $\begin{array}{c}\text { Average } \\
\text { population }\end{array}$ & 15000 & 20000 & 15000 & 5000 & 10000 \\
\hline $\begin{array}{c}\text { Average flow } \\
\text { m3/day }\end{array}$ & 3000 & 4000 & 3000 & 1300 & 2000 \\
\hline $\begin{array}{c}\text { Average load } \\
\text { removed } \\
\text { kg/day) }\end{array}$ & 644 & 3500 & 353 & 391 & 379 \\
\hline $\begin{array}{c}\text { Efficiency } \\
\% \text { BOD }\end{array}$ & 76 & 89 & 45 & 88 & 68 \\
\hline $\begin{array}{c}\text { Efficiency } \\
\% \text { COD }\end{array}$ & 70 & 89 & 59 & 87 & 66 \\
\hline
\end{tabular}




\begin{tabular}{|c|c|c|c|c|c|}
\hline $\begin{array}{c}\text { Efficiency } \\
\% \text { TSS }\end{array}$ & 74 & 87 & 53 & 86 & 65 \\
\hline $\begin{array}{c}\text { Power cost/Kg } \\
\text { BOD removed }\end{array}$ & 0.1 & 0.3 & 0.03 & 0.1 & 0 \\
\hline Power cost/m3 & 0.06 & 0.1 & 0.01 & 0.02 & 0 \\
\hline $\begin{array}{c}\text { Cost of } \\
\text { operation and } \\
\text { consumables/m3 }\end{array}$ & 0.2 & 0.4 & 0.2 & 0.2 & 0.1 \\
\hline $\begin{array}{c}\text { Construction } \\
\text { cost } 1000 / \mathrm{m} 3\end{array}$ & 6 & 8 & 4 & 1 & 5 \\
\hline $\begin{array}{c}\text { Cost of } \\
\text { operation and } \\
\text { consumables/ } \\
\text { Kg BOD } \\
\text { removed }\end{array}$ & 0.2 & 1.2 & 1 & 1.4 & 1.3 \\
\hline $\begin{array}{c}\text { Specific surface } \\
\text { area (m2/m3) }\end{array}$ & 17 & 3 & 0.6 & 2 & 15 \\
\hline
\end{tabular}

( SBR): Sequencing Batch Reactor

(AL) : Aerated lagoon

)RBC) : Rotating Biological Contactors

(UASB) : Up flow anaerobic sludge bed

(WL) : Wetlands

(WSP) : Waste stabilization ponds

(CO) : Conventional activated sludge

(AS) : Surface aeration

(EX) : Extended aeration

(TF) : Trickling filters

$(\mathrm{OX})$ : Oxidation ditches

Table 3: Technical and economic data characterizing selection matrix for Decentralized WWTP

\begin{tabular}{|c|c|c|c|c|c|}
\hline $\begin{array}{l}\text { Decentralized } \\
\text { WWTP }\end{array}$ & \multicolumn{5}{|c|}{ Types of technologies } \\
\hline Indicators & ABR & DBAF & WL & AS & WSP \\
\hline $\begin{array}{l}\text { Average } \\
\text { population }\end{array}$ & 1500 & 5500 & 4500 & 10000 & 7000 \\
\hline $\begin{array}{l}\text { Average flow } \\
\text { m3/day }\end{array}$ & 200 & 500 & 500 & 1000 & 1000 \\
\hline $\begin{array}{l}\text { Average load } \\
\text { removed } \\
\text { (kg/day) }\end{array}$ & NA & NA & 16 & 350 & 318 \\
\hline $\begin{array}{l}\text { Efficiency } \\
\% \text { BOD }\end{array}$ & NA & 66 & 83 & 85 & 80 \\
\hline $\begin{array}{l}\text { Efficiency } \\
\% \text { COD }\end{array}$ & NA & 66 & 73 & 85 & 80 \\
\hline $\begin{array}{l}\text { Efficiency } \\
\text { \%TSS }\end{array}$ & NA & 70 & 80 & 85 & 80 \\
\hline $\begin{array}{l}\text { Cost of } \\
\text { operation and } \\
\text { consumables } / \mathrm{m} 3\end{array}$ & 0.2 & 0.08 & 0.03 & 0.03 & 0.01 \\
\hline $\begin{array}{l}\text { Construction } \\
\text { cost } 1000 / \mathrm{m} 3\end{array}$ & NA & NA & 1.6 & 0.014 & 0.042 \\
\hline $\begin{array}{l}\text { Cost of } \\
\text { operation and } \\
\text { consumables/ } \\
\text { Kg BOD } \\
\text { removed }\end{array}$ & 2.9 & 1.7 & 5.5 & 1.4 & 2.4 \\
\hline
\end{tabular}

(ABR) : Anaerobic Filters

(AS) : Activated sludge

(WL) : Wetlands

(DABF) : Biological Aerated Filter

(WSP) : Waste stabilization pond

Note: ABR-DBAF plants have values are not

available so they must be excluded.

\subsection{Data Processing}

In the previous step, the values of 12 factors for 11 centralized WWTPs and the values of 9 factors for 5 decentralized WWTPs are divided to two groups as follows:

The higher the value of factors in (Group 1), the better they are. These factors for Centralized and Decentralized systems are Efficiency \%BOD, Efficiency \%COD, Efficiency \%TSS, Average population, Average flow m3/day, and Average load removed $(\mathrm{kg} /$ day)

The lower the value of factors in (Group 2), the better they are. These factors for Centralized systems are Construction cost $1000 / \mathrm{m}^{3}$, Cost of operation and consumables/ Kg BOD removed, Specific surface area $\left(\mathrm{m}^{2} / \mathrm{m}^{3}\right)$, Power cost $/ \mathrm{Kg}$ BOD removed, Power cost $/ \mathrm{m}^{3}$, and Cost of operation and consumables $/ \mathrm{m}^{3}$.

And for Decentralized systems are, Cost of operation and consumables $/ \mathrm{m}^{3} \quad$, Construction cost $1000 / \mathrm{m}^{3}$, and Cost of operation and consumables/ $\mathrm{Kg}$ BOD removed.

The two groups (Group 1 and Group 2) are opposite in order when judging the importance of factor. Therefore, these groups have been needed to put in a same scale or order to have right comparison. In order to do that, we calculated the relative weights of plants for each factor. (Group 1) of factors should be graded in an ascending order by making highest value equal one and the lowest value equal zero, then range the values between them to numbers between one and zero. The relative weight should equal one for the plant that has maximum value for this factor, but the relative weight equal zero for the plant that has minimum value of this factor. Group (2) of factors should be graded in an descending order by making highest value equal zero and the lowest value equal one, then range the values between them to numbers between one and zero .The relative weight should equal zero for the plant that has maximum value for this factor, but the relative weight equal one for the plant that has minimum value of this factor .

\subsection{Evaluation Parameters}

In order to distinguish between the plants, the sum of the values for the factors of the 11 centralized systems and 5 decentralized systems have been calculated. Due to that their boundaries are not from the same unit or value, they must be unified through the factors that were resulted by the questionnaire. That will give the factor a new value of equalized unit (value can be added). The questionnaire has been given to experts to evaluate the factors for getting relative weights of them. Expert can evaluate the factors according to his importance by choosing a mark from the lowest value one to the highest value ten.

\subsection{How to Calculate the Relative Weights for Factors}

After collecting the results of the questionnaire, we put each value from 1 to 10 has been put its number of experts who choose it to evaluate each factor. Then the 
relative weights have been calculated for factors as follows:

\section{Centralized WWTPs}

The number of experts who choose this mark has been counted (from 1 to 10) to evaluate this factor as follows:

$V_{i y}=$ The number of the experts who choose this mark to evaluate this factor

$\mathrm{y}=(1$ to10) (refers to marks)

$\mathrm{i}=$ (1 to 12$)$ (refers to factors)

For each factor, we can get the total weight by multiplying the chosen marks by experts (from 1 to 10) then summiting them. This can be calculated by using the following equation:

$$
\mathrm{n}_{\mathrm{i}}=\sum_{\mathrm{y}=1}^{\mathrm{y}=10}\left(\mathrm{y} * \mathrm{~V}_{\mathrm{iy}}\right)
$$

Then divide this total weight $\left(n_{i}\right)$ to the maximum weight which any of these factors can be, that equals (400), This can be calculated by using the following equation:

$$
\mathrm{N}_{\mathrm{i}}=\mathrm{n}_{\mathrm{i}} / 400
$$

Relative weights for each factor can be calculated by the following equation:

\section{Decentralized WWTPs}

$$
\mathrm{R}_{\mathrm{i}}=\mathrm{N}_{\mathrm{i}} / \sum_{\mathrm{i}=1}^{\mathrm{i}=12}\left(\mathrm{~N}_{\mathrm{i}}\right)
$$

In order to calculate relative weights for factors the number of experts who choose this mark has been counted (from 1 to 10 ) to evaluate this factor as follows:

$V_{i y}=$ The number of the experts who choosed this mark to evaluate this factor

$\mathrm{y}=(1$ to10) (refers to marks)

$\mathrm{i}=(1$ to 9$)$ (refers to factors)

For each factor, the total weight has been calculated by multiplying the chosen marks by experts (from 1 to 10) then summiting them. This can be calculated by using the following equation:

$$
\mathrm{n}_{\mathrm{i}}=\sum_{\mathrm{y}=1}^{\mathrm{y}=10}\left(\mathrm{y} * \mathrm{~V}_{\mathrm{iy}}\right)
$$

Then divide this total weight $\left(n_{i}\right)$ to the maximum weight which any of these factors can be, that equals (400), This can be calculated by using the following equation:

$$
\mathrm{N}_{\mathrm{i}}=\mathrm{n}_{\mathrm{i}} / 400
$$

Relative weights for each factor can be calculated by the following equation:

$$
\mathrm{R}_{\mathrm{i}}=\mathrm{N}_{\mathrm{i}} / \sum_{\mathrm{i}=1}^{\mathrm{i}=9}\left(\mathrm{~N}_{\mathrm{i}}\right)
$$

\subsection{Calculation of Data Modification for WWTPs}

The following table shows the results of data processing for wastewater treatment plants that has been calculated in step (2) and the results of the relative weights of factors that have been calculated in step (4). the final modified data for wastewater treatment plants has been calculated as follow.
The final modified data for plants has been calculated by using the following equation:

$$
\mathrm{C}_{\mathrm{ij}}=\mathrm{c}_{\mathrm{ij}} * \mathrm{R}_{\mathrm{i}}
$$

$C_{i j}=$ Final modified data about plant (j) and for factor (i).

$R_{i}=$ Relative weight of factor (i).

$c_{i j}=$ Relative weight of plant (i) for factor (j) .

i refers to factors (1 to 12)

$\mathrm{j}$ refers to systems (1 to 11 )

After calculating the modified data values for the plants the total weight has been calculated by collecting all the values of the factors for each plant of them by using the following equation:

$$
C_{i}=\sum_{i=1}^{i=12} C_{i j}
$$

$C_{i}=$ Total Weight for plant (i).

$C_{i j}=$ Final modified data about plant $\mathrm{j}$ and for factor $\mathrm{i}$.

i refers to factors (1 to 12)

$\mathrm{j}$ refers to systems (1 to 11 )

Decentralized WWTPs

The final modified data values for plants have been calculated by using the following equation:

$$
C_{i j}=c_{i j} * R_{i}
$$

$C_{i j}=$ Final modified data about plant $\mathrm{j}$ and for factor (i). $R_{i}==$ Relative weight of factor (i).

$c_{i j}=$ Relative weight of plant (i) for factor (j).

(i) Refers to factors ( 1 to 9)

(j) Refers to systems (1 to 5)

After calculating the modified data values for the plants the total weight has been calculated by collecting all the values of the factors for each plant of them by using the following equation:

$$
C_{i}=\sum_{i=1}^{i=9} C_{i j}
$$

$C_{i}=$ Total weight for plant (i).

$C_{i j}=$ Final modified data about plant (j) and for factor (i).

(i) Refers to factors (1 to 9)

(j) Refers to systems (1 to 3 )

\section{Results and Discussion}

\subsection{Results of Data Processing}

The data processing results for centralized and decentralized wastewater treatment plants which were divided to two groups have been showed as follows .

\section{Centralized WWTPs}




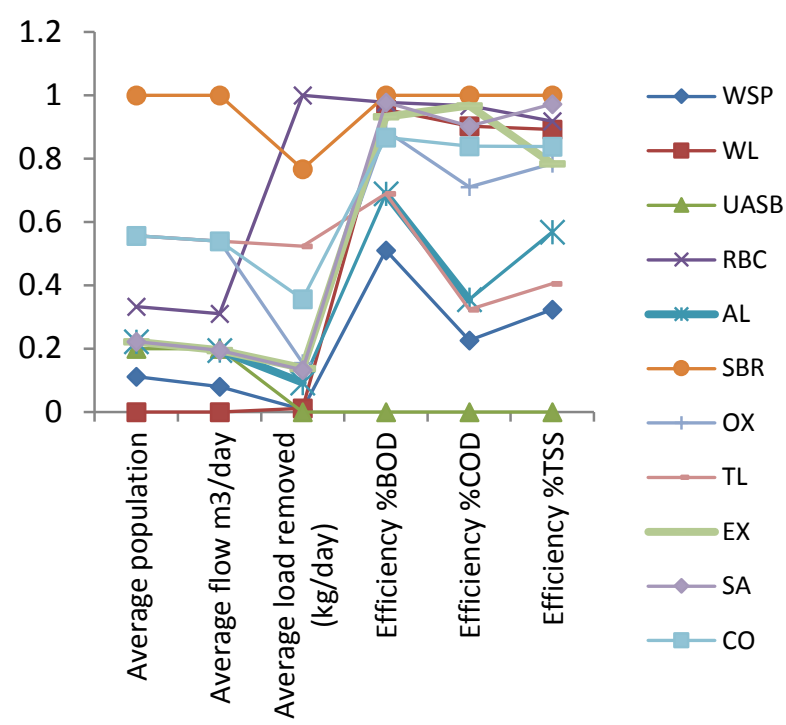

Figure 1: Relative weights for group 1 of factors for Centralized WWTPs

The results for Centralized wastewater treatment plants are in the following figures:

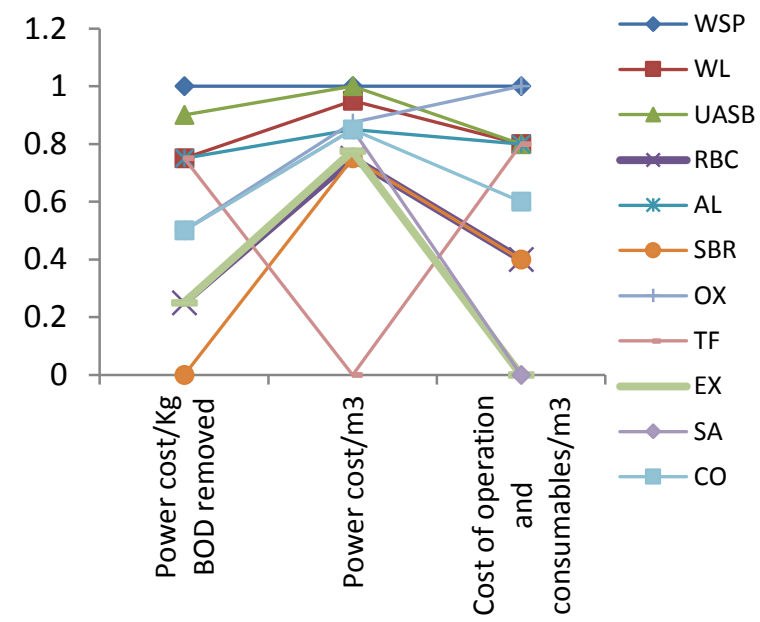

Figure 2: Relative weights (I) for group 2 of factors for Centralized WWTPs

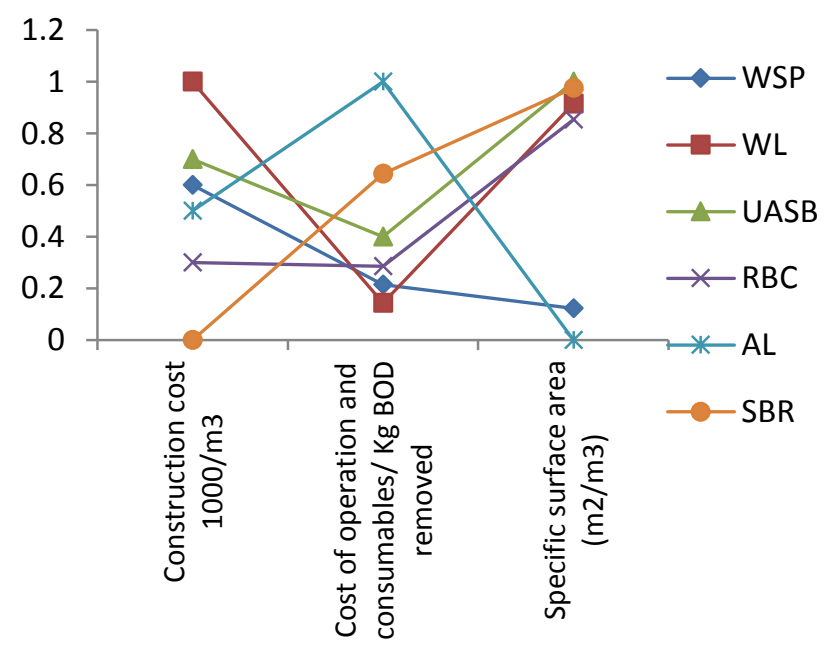

Figure 3: Relative Weights (II) for group 2 of factors for Centralized WWTPs
The results for Decentralized wastewater treatment plants are in the following figures:

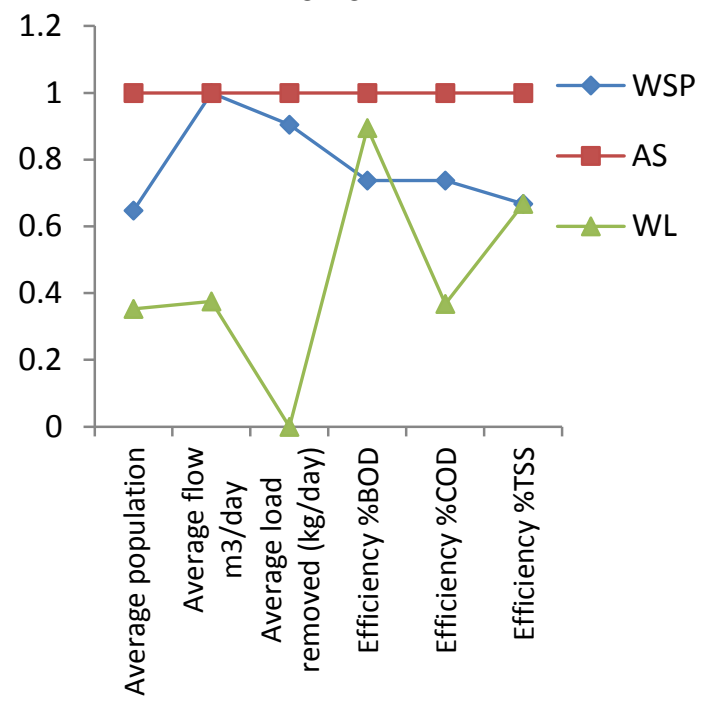

Figure 4: Relative Weights for group 1 of factors for Decentralized WWTPs

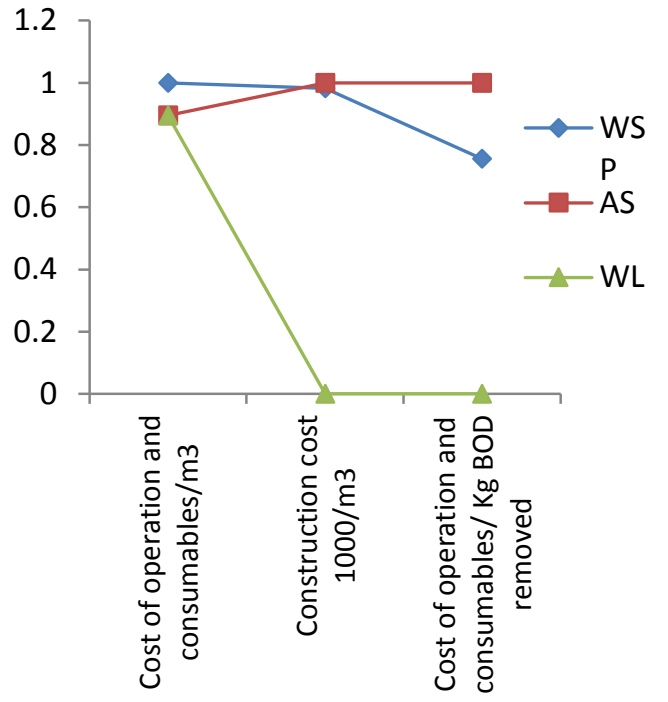

Figure 5: Relative Weights for group 2 of factors for Decentralized system

Figure 1 shows that SBR plant has the highest values for 5 of these factors and UASB plant has the least values for 4 of these factors. We found that SBR is the best plant that achieved the purpose of the construction. Figure 2 shows that WSP-WL-UASB plants have the highest values for these factors and TF plant has the least value for power cost. Figure 3 shows that WSP and AL plants are the most plants that need large areas to set up compared to other plants. Figure 4 shows that AS plant is the most system that has achieved the purpose of the construction followed by WSP. Figure 5 shows that AS plant has the least cost followed by WSP plant. 


\subsection{Results of Relative Weights Calculations}

After applying the pervious equations, the relative weights for each factor have been calculated and then will show results as follows.

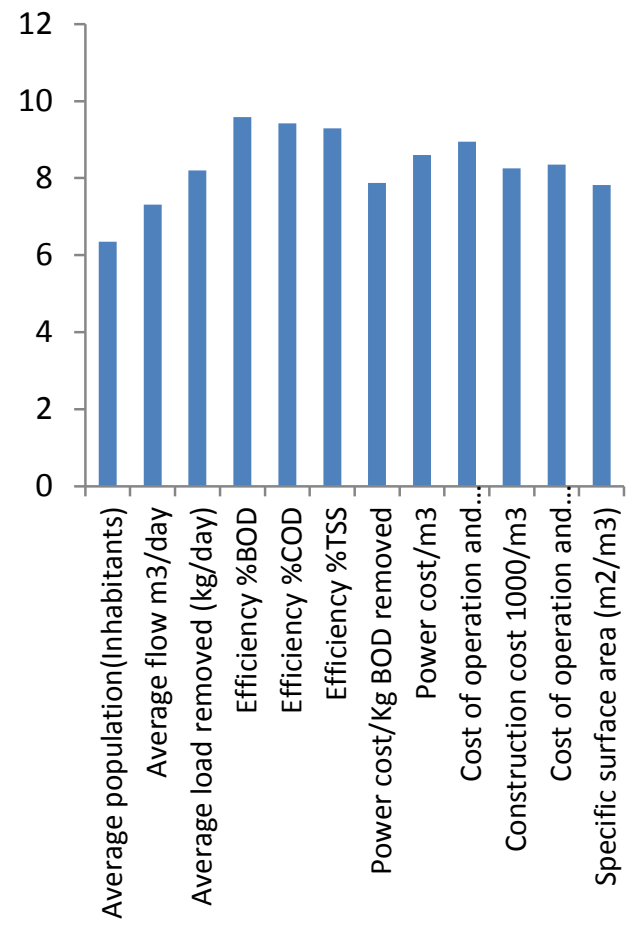

Figure 6: Relative Weights percentages of Centralized WWTPs factors

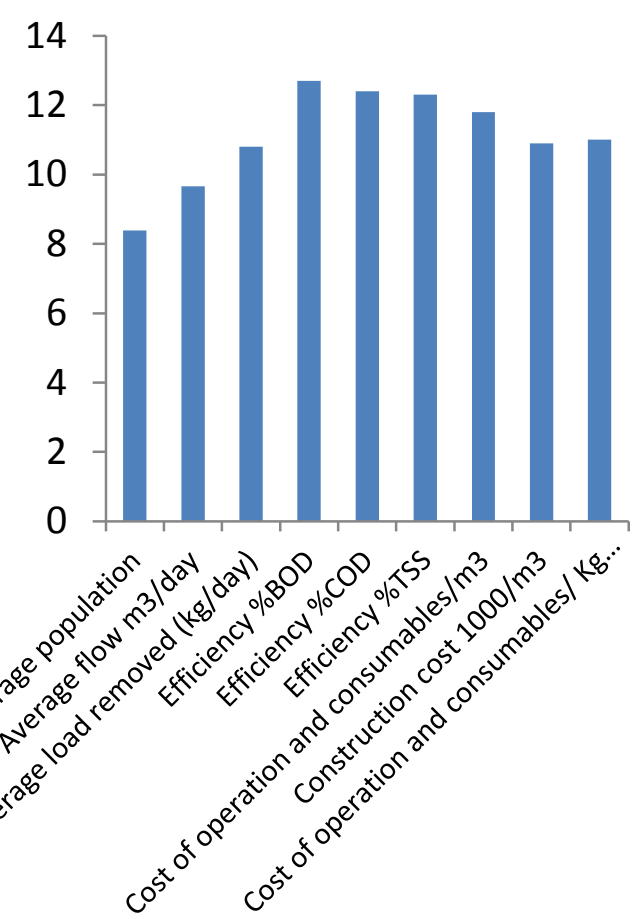

Figure 7: Relative Weights percentages of Decentralized WWTPs factors

\section{3.Results of data modification for WWTPs} By using equation (7), the modified data values for Centralized WWTPs have been showed in the following table:

Table 4: Final modified data for Centralized WWTPs[(CO - SA- EX- TF- OX- SBR) plants]

\begin{tabular}{|c|c|c|c|c|c|c|}
\hline \multirow{3}{*}{$\begin{array}{c}\text { Centralized } \\
\text { WWTP }\end{array}$} & \multicolumn{6}{|c|}{ Aerobic } \\
\hline & \multicolumn{6}{|c|}{ Types of technologies } \\
\hline & $\mathrm{CO}$ & SA & EX & TL & $\mathrm{OX}$ & SBR \\
\hline $\begin{array}{c}\text { Average } \\
\text { population }\end{array}$ & 0.035 & 0.014 & 0.014 & 0.035 & 0.035 & 0.064 \\
\hline $\begin{array}{l}\text { Average } \\
\text { flow } \\
\text { m3/day }\end{array}$ & 0.039 & 0.014 & 0.014 & 0.039 & 0.039 & 0.073 \\
\hline $\begin{array}{l}\text { Average } \\
\text { load } \\
\text { removed } \\
\text { (kg/day) }\end{array}$ & 0.029 & 0.011 & 0.011 & 0.043 & 0.013 & 0.063 \\
\hline $\begin{array}{c}\text { Power } \\
\text { cost/Kg } \\
\text { BOD } \\
\text { removed }\end{array}$ & 0.039 & 0.039 & 0.02 & 0.059 & 0.039 & 0 \\
\hline $\begin{array}{c}\text { Power } \\
\text { cost/m3 }\end{array}$ & 0.073 & 0.073 & 0.067 & 0 & 0.075 & 0.065 \\
\hline $\begin{array}{l}\text { Cost of } \\
\text { operation } \\
\text { and } \\
\text { consumabl } \\
\text { es/m3 }\end{array}$ & 0.054 & 0 & 0 & 0.072 & 0.089 & 0.036 \\
\hline $\begin{array}{c}\text { Constructi } \\
\text { on cost } \\
1000 / \mathrm{m} 3\end{array}$ & 0.074 & 0.078 & 0.033 & 0.041 & 0.066 & 0 \\
\hline $\begin{array}{l}\text { Cost of } \\
\text { operation } \\
\text { and } \\
\text { consumabl } \\
\text { es/ Kg } \\
\text { BOD } \\
\text { removed }\end{array}$ & 0 & 0.012 & 0.012 & 0.066 & 0.084 & 0.054 \\
\hline $\begin{array}{r}\text { Specific } \\
\text { surface } \\
\text { area } \\
(\mathrm{m} 2 / \mathrm{m} 3)\end{array}$ & 0.072 & 0.072 & 0.067 & 0.067 & 0.072 & 0.076 \\
\hline $\begin{array}{r}\text { Efficiency } \\
\% \text { BOD }\end{array}$ & 0.083 & 0.094 & 0.089 & 0.066 & 0.085 & 0.096 \\
\hline $\begin{array}{r}\text { Efficiency } \\
\% \text { COD }\end{array}$ & 0.079 & 0.085 & 0.091 & 0.03 & 0.067 & 0.094 \\
\hline $\begin{array}{r}\text { Efficiency } \\
\% \mathrm{TSS}\end{array}$ & 0.078 & 0.09 & 0.073 & 0.038 & 0.073 & 0.093 \\
\hline
\end{tabular}


Table 5: Final modified data for Centralized WWTPs[(AL - RBC- UASB- WL- WSP) plants]

\begin{tabular}{|c|c|c|c|c|c|}
\hline \multirow{3}{*}{$\begin{array}{c}\text { Centralized } \\
\text { WWTP }\end{array}$} & \multicolumn{2}{|c|}{ Aerobic } & Anaerobi & \multicolumn{2}{|c|}{ Natural Treatment } \\
\hline & \multicolumn{5}{|c|}{ Types of technologies } \\
\hline & AL & $\mathrm{RBC}$ & UASB & WL & WSP \\
\hline $\begin{array}{c}\text { Average } \\
\text { population }\end{array}$ & 0.014 & 0.021 & 0.014 & 0 & 0.01 \\
\hline $\begin{array}{c}\text { Average } \\
\text { flow } \\
\text { m3/day }\end{array}$ & 0.014 & 0.023 & 0.014 & 0 & 0.01 \\
\hline $\begin{array}{l}\text { Average } \\
\text { load } \\
\text { removed } \\
\text { (kg/day) }\end{array}$ & 0.008 & 0.082 & 0 & 0.001 & 0 \\
\hline $\begin{array}{l}\text { Power } \\
\text { cost } / \mathrm{Kg} \\
\mathrm{BOD} \\
\text { removed }\end{array}$ & 0.059 & 0.02 & 0.073 & 0.059 & 0.08 \\
\hline $\begin{array}{c}\text { Power } \\
\text { cost } / \mathrm{m} 3\end{array}$ & 0.073 & 0.065 & 0.084 & 0.082 & 0.09 \\
\hline $\begin{array}{l}\text { Cost of } \\
\text { operation } \\
\text { and } \\
\text { consumabl } \\
\text { es/m3 }\end{array}$ & 0.072 & 0.036 & 0.072 & 0.072 & 0.09 \\
\hline $\begin{array}{c}\text { Constructi } \\
\text { on cost } \\
1000 / \mathrm{m} 3\end{array}$ & 0.041 & 0.025 & 0.058 & 0.083 & 0.05 \\
\hline $\begin{array}{l}\text { Cost of } \\
\text { operation } \\
\text { and } \\
\text { consumabl } \\
\text { es/ Kg } \\
\text { BOD } \\
\text { removed }\end{array}$ & 0.084 & 0.024 & 0.036 & 0.012 & 0.02 \\
\hline $\begin{array}{c}\text { Specific } \\
\text { surface } \\
\text { area } \\
(\mathrm{m} 2 / \mathrm{m} 3) \\
\end{array}$ & 0 & 0.067 & 0.078 & 0.072 & 0.01 \\
\hline $\begin{array}{c}\text { Efficiency } \\
\% \text { BOD }\end{array}$ & 0.066 & 0.094 & 0 & 0.092 & 0.05 \\
\hline $\begin{array}{c}\text { Efficiency } \\
\% \text { COD }\end{array}$ & 0.033 & 0.091 & 0 & 0.085 & 0.02 \\
\hline $\begin{array}{c}\text { Efficiency } \\
\% \text { TSS }\end{array}$ & 0.053 & 0.085 & 0 & 0.083 & 0.03 \\
\hline
\end{tabular}

By using equation (8), we can get the Total Weights values for Centralized WWTPs, showed in the following figure:

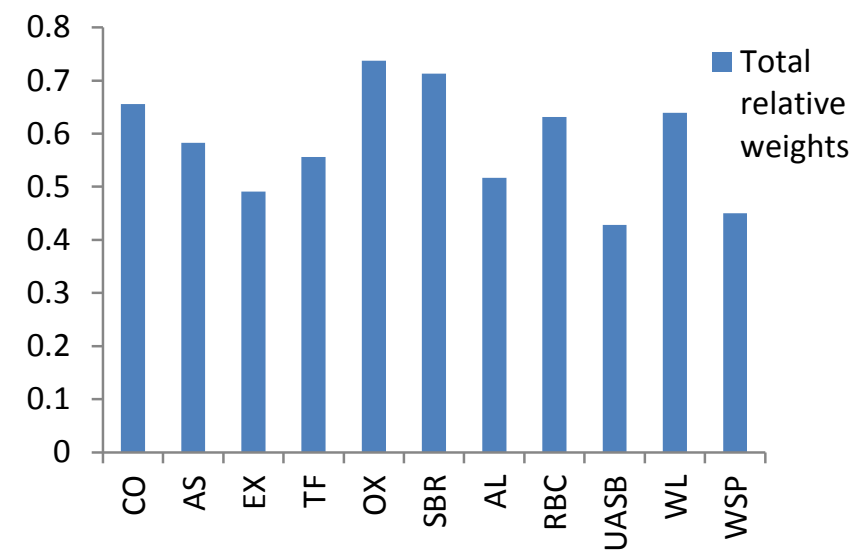

Figure 8: Total Relative Weights for Centralized WWTPs
Decentralized WWTPs

By applying equation (9), the final modified data for Decentralized WWTPs have been showed in the following table:

Table 4: Final modified data for Decentralized WWTPs

\begin{tabular}{|l|c|c|c|c|c|}
\hline $\begin{array}{l}\text { Decentral-ized } \\
\text { WWTP }\end{array}$ & \multicolumn{5}{|c|}{ types of technologies } \\
\hline Indicators & ABR & DBAF & WL & AS & WSP \\
\hline $\begin{array}{l}\text { Average } \\
\text { population }\end{array}$ & 0 & 0.0395 & 0.0296 & 0.0839 & 0.0543 \\
\hline $\begin{array}{l}\text { Average flow } \\
\text { m3/day }\end{array}$ & 0 & 0.0362 & 0.0362 & 0.0966 & 0.0966 \\
\hline $\begin{array}{l}\text { Average load } \\
\text { removed } \\
\text { (kg/day) }\end{array}$ & NA & NA & 0 & 0.1083 & 0.0979 \\
\hline $\begin{array}{l}\text { Efficiency } \\
\% \text { BOD }\end{array}$ & NA & 0 & 0.1133 & 0.1266 & 0.0933 \\
\hline $\begin{array}{l}\text { Efficiency } \\
\% \text { COD }\end{array}$ & NA & 0 & 0.0458 & 0.1245 & 0.0917 \\
\hline $\begin{array}{l}\text { Efficiency } \\
\% \text { TSS }\end{array}$ & NA & 0 & 0.0818 & 0.1227 & 0.0818 \\
\hline $\begin{array}{l}\text { Cost of } \\
\text { operation and } \\
\text { consumables/m3 }\end{array}$ & 0 & 0.0747 & 0.1057 & 0.1057 & 0.1181 \\
\hline $\begin{array}{l}\text { Construction } \\
\text { cost 1000/m3 }\end{array}$ & NA & Na & 0 & 0.109 & 0.107 \\
\hline $\begin{array}{l}\text { Cost of } \\
\text { operation and } \\
\text { consumables/ } \\
\text { Kg BOD } \\
\text { removed }\end{array}$ & 0.07 & 0.102 & 0 & 0.1104 & 0.0834 \\
\hline
\end{tabular}

By applying equation (10), we get the result of the Total Weights for Decentralized WWTPs, showed in the following figure:

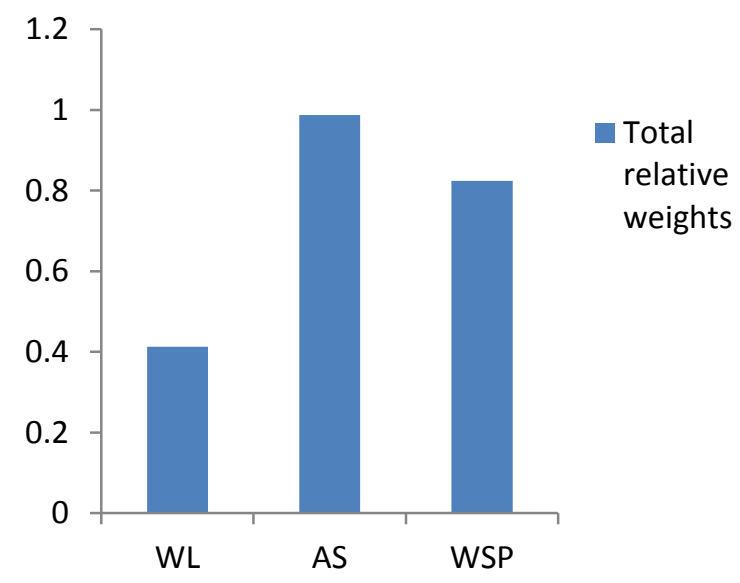

Figure 9: Total Relative Weights for Decentralized WWTPs

\subsection{Comparing Between WWTPs}

After calculating total values of weights for all plants by collecting all values of factors for each plant, we could compare between their total weights to choose the highest values. 
Centralized WWTPs

Table 5: Arrangement of plants according to total weights for centralized WWTPs

\begin{tabular}{|l|l|l|l|l|l|l|}
\hline & 1 & 2 & 3 & 4 & 5 & 6 \\
\hline Plant & OX & SBR & CO & WL & RBC & AS \\
\hline $\begin{array}{l}\text { Relative } \\
\text { Weights }\end{array}$ & 0.737 & 0.713 & 0.656 & 0.639 & 0.631 & 0.583 \\
\hline
\end{tabular}

\begin{tabular}{|l|l|l|l|l|l|}
\hline & 7 & 8 & 9 & 10 & 11 \\
\hline Plant & TF & AL & EX & WSP & UASB \\
\hline $\begin{array}{l}\text { Relative } \\
\text { Weights }\end{array}$ & 0.556 & 0.517 & 0.491 & 0.45 & 0.428 \\
\hline
\end{tabular}

Table 5 shows that the plant which has the highest Total Weight of Centralized WWTPs is OX $=0.737$ followed by $\mathrm{SBR}=0.713, \mathrm{CO}=0.656, \mathrm{WL}=0.639$, $\mathrm{RBC}=0.631, \mathrm{AS}=0.583, \mathrm{TF}=0.556, \mathrm{AL}=0.517$, $\mathrm{EX}=0.491, \mathrm{WSP}=0.45$ and $\mathrm{UASB}=0.428$

Decentralized WWTPs

Table 6: Arrangement of plants according to Total Weights for Decentralized WWTPs

\begin{tabular}{|l|l|l|l|}
\hline No. & 1 & 2 & 3 \\
\hline Plant & AS & WSP & AL \\
\hline Total Weights & 0.988 & 0.824 & 0.413 \\
\hline
\end{tabular}

Table 6 shows that the plant which has the highest Total Weight for Decentralized WWTPs is AS plant $=0.988$, followed by WSP plant $=0.824$, and WL plant $=0.413$

\section{Conclusions}

-The best three centralized wastewater treatment plants were from the aerobic treatment and they are (Oxidation Ditch - Sequence Batch Reactor - Activated Sludge) plants.

-The best Decentralized wastewater treatment plant is Activated Sludge plant and Waste Stabilization Pond plant.

\section{References}

[1] http://www.sswm.info/category/implementationtools/wastewater-treatment/hardware/semi-centralisedwastewater-treatments-3

[2] Mohamed Elhosseiny, "technical report of sewage pump station \&treatment plants for sinbo village zefta markaz ghabiya government ", life project - USAID, JULY 2005.

[3] "Explaining the Activated Sludge Process", spring 2003, vol.14,no.2, Pipe Line.

[4] Hlthmana, "df Health Manual " vol. 20, part8, chp.2.

[5] Jules B. Van Lier, Nidal Mahmoud And Grietje Zeeman, "Anaerobic Wastewater Treatment",2008.
[6] Waste Stabilization Ponds and Constructed Wetlands Manual Design, UNEP-IETC with the Danish International Development Agency (Danida)

[7] FOXON, K.M.; PILLAY, S.; LALBAHADUR, T.; RODDA, N.; HOLDER, F.; BUCKLEY, C.A. (2004): "The anaerobic baffled reactor (ABR)- An appropriate technology for on-site sanitation". In: Water SA 30, 5.

[8] SASSE, L. ; BORDA (Editor) (1998): "DEWATS. Decentralised Wastewater Treatment in Developing Countries". Bremen: Bremen Overseas Research and Development Association (BORDA).

[9] U.S. EPA (Editor) (2006): "Emerging Technologies for Biosolids Management". (= EPA 832-R, 5/6). United States Environmental Protection Agency, Office of Wastewater Management.

[10] Mai M. Afifi, "Assessment and Application of Low Cost Technologies for Rural Sanitation in Egypt", Faculty Of Engineering, Ain Sham University for the fulfillment of the requirement of M.Sc. degree in Civil Engineering, 2015. 